\title{
PERBEDAAN TINGKAT KEPUASAN MAKAN PASIEN DI RUMAH SAKIT BERSERTIFIKAT HALAL DENGAN YANG BELUM BER- SERTIFIKAT HALAL
}

\author{
Differences of Eat Satisfaction Levels of Patients In Hospital With Halal Certified and \\ Non-Certified
}

\section{Arina Zulfa Azizah ${ }^{1}$, Joyeti Darni ${ }^{1}$, Amilia Yuni Damayanti ${ }^{1}$, Mira Dian Naufalani ${ }^{1}$}

${ }^{1}$ Program Studi SI Gizi, Fakultas Ilmu Kesehatan, Universitas Darussalam Gontor

Diterima: 09 Mei 2019; Revisi: 15 Juli 2019; Diterbitkan: 30 Juli 2019

\section{Abstract}

Background: Satisfaction can be influenced by several factors, including the diversity of products, quality products, quality of service, satisfying facilities, location, prices and halal labels. Objective: The purpose of the study was to determine the differences in eating satisfaction patients in hospital with halal certified and non-certified. Method: The research method included a comparative study with independent samples using Cross-sectional design carried out on 134 respondents (67 respondents at Sultan Agung Islamic Hospital and 67 respondents at Roemani Muhammadiyah Hospital). The study was conducted on the target sample; this is all patients who were undergoing treatment at Class II and III care rooms. Analyzes using the Mann Whitney test were carried out. Assessment of patient satisfaction was collected using a questionnaire. Results: The level of patient satisfaction in the management of food at Hospital Certified Halal $(\mathrm{HCH})$, showed $50.7 \%$ of respondents were satisfied, and $49.3 \%$ of respondents felt very satisfied while in the management of food at Non Certified Hospital (NCH) $100 \%$ of respondents were satisfied to the management of food at NCH . Conclusion: There was differences in the level of the patient in the hospital with halal certified and noncertified this is $\mathrm{p}$-value $<0,005$.

Keywords: Food, patient satisfaction, halal certificate hospital

\section{Abstrak}

Latar Belakang: Kepuasan dapat dipengaruhi oleh beberapa faktor, termasuk keragaman produk, kualitas produk, kualitas layanan, fasilitas yang memuaskan, lokasi, harga dan label halal. Tujuan: Untuk mengetahui perbedaan kepuasan makan pasien di rumah sakit bersertifikat halal dengan yang belum bersertifikat halal. Metode: Metode penelitian termasuk studi komparatif dengan sampel independen menggunakan desain cross-sectional yang dilakukan pada 134 responden (67 responden di Rumah Sakit Islam Sultan Agung dan 67 responden di Rumah Sakit Roemani Muhammadiyah). Penelitian dilakukan pada target sempel yaitu semua pasien yang menjalani perawatan di ruang perawatan Kelas II dan III. Analisis menggunakan uji Mann Whitney. Penilaian kepuasan pasien dikumpulkan menggunakan kuesioner. Hasil: Tingkat kepuasan pasien dalam penyelenggaraan makanan di Hospital Certified Halal $(\mathrm{HCH})$, menunjukkan $50,7 \%$ responden puas dan $49,3 \%$ responden merasa sangat puas sedangkan pada penyelenggaraan makanan di Non Certified Hospital (NCH) $100 \%$ responden puas dengan penyelenggaraan makananan di NCH. Kesimpulan: Ada perbedaan tingkat kepuasan makan pasien di rumah sakit bersertifikat halal dengan yang belum bersertifikat halal halal be $p$-value $<0,005$.

Kata Kunci: Makanan, kepuasan pasien, sertifikat halal rumah sakit

*Korespondensi: Arina Zulfa Azizah, Email : arinnazulfaazizah@gmail.com

DOI : $10.22487 / \mathrm{j} 26227622.2019 . v 3.11 .12668$

\section{PENDAHULUAN}

Berkembangnya zaman, ilmu pengetahuan dan teknologi semakin berkembang termasuk bagaimana cara mengolah makanan. Sekarang banyak pembuatan makanan yang bersifat kompleks dan makanan tersebut dibuat dari kandungan yang tidak semuanya jelas kehalalannya (Syifa, 2013). Dalam Alqur'an surat al-Maidah [3]:88 Allah Swt jelas sekali memperintahkan umat islam untuk mengkonsumsi makanan Halal dan Baik.

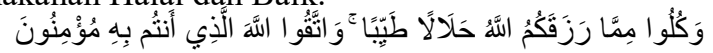

" Dan makanlah dari apa yang telah diberikan Allah kepadamu sebagai rezeki yang halal dan baik, dan bertakwalah kepada Allah yang kamu beriman kepada-Nya"(QS. Almaidah: 88).

Indonesia adalah negara dengan jumlah penduduk muslim terbesar dunia menurut The Pew Forum on Religion and Public Life penganut agama Islam di Indonesia sebesar 209,1 juta jiwa atau 87,2 persen dari total penduduk (The Pew Forum on Religion and Public Life, 2010). Sebagai negara berpenduduk muslim terbesar tentu saja berkepentingan dengan peredaran produk yang aman 
dan berstandar halal (Hidayat, 2015). Menurut Undang -undang Pasal 8 Ayat 1 maka sepatutunya konsumen dalam negeri mendapatkan perlindungan dalam memperoleh kepastian tentang kehalalan produk pangan yang beredar. Menurut Undang-undang No 33 tahun 2014 tentang Jaminan Produk Halal antara lain pasal 4 yang menyatakan bahwa produk yang masuk, beredar dan diperdagangkan di Indonesia wajib bersertifikat Halal (Presiden Republik Indonesia, 2014).

Mengkonsumsi makanan halal merupakan kewajiban agama yang bernilai ibadah, memberikan kebaikan bagi kehidupan di dunia dan akhirat dan manifestasi dari rasa syukur kepada Allah atas segala nikmat-Nya (Faidah, 2017). Pangan halal merupakan pangan yang memenuhi syariat agama Islam baik dari segi bahan baku, bahan tambahan yang digunakan maupun cara produksinya sehingga pangan tersebut dapat dikonsumsi oleh orang Islam tanpa berdosa (Muchtar, 2013).

Data dari State of The Global Islamic Economy 2014-2015 menyebutkan indikator tren bisnis halal terlihat pada lima bidang industri terus menunjukan kemajuan, antara lain jasa keuangan islami (Islamic Finance), makanan halal, busana muslim, media dan rekreasi halal, serta farmasi dan kosmetik halal (Sholeh, 2015). Harapan dan ekspektasi tentang pelayanan kesehatan berbasis nilai-nilai syariah yang terus mengalir dari masa ke masa sesungguhnya sangat relevan dengan pesan Islam yang menjelaskan bahwa semua segmen kehidupan termasuk didalamnya pengelolaan rumah sakit wajib berlandaskan pada syariah Islam (Sulistiadi, 2016). Sebagaimana firman Allah :

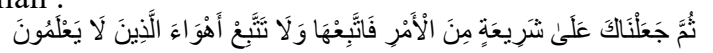

"Kemudian Kami jadikan kamu berada diatas suatu syariat (peraturan) dari urusan (agama itu), maka ikutilah syariat itu dan janganlah kamu ikuti hawa nafsu orang-orang yang tidak mengetahui". (QS. AlJatsiyah:18).

Pelayanan yang memuaskan dan berkualitas akan membentuk loyalitas pasien/pelanggan, dan kepuasan sangat erat hubungannya dengan "word of mouth", maka pelayanan yang memuaskan tersebut juga akan mendatangkan pelanggan baru (Kuntoro, 2017). Kepuasan konsumen bisa dipengaruhi oleh beberapa faktor, diantaranya keberagaman produk, produk yang berkualitas, kualitas pelayanan, fasilitas yang memuaskan, lokasi, dan harga, label halal (Wahyunita, 2016).

Rumah Sakit Islam Sultan Agung merupakan rumah sakit yang menerapkan sistem Penyelanggaraan makanan yang sudah bersertifikat Halal. Rumah Sakit Islam Sultan Agung memiliki motto "Mencintai Allah dan Menyayangi sesama" dari motto tersebut melandasi Rumah Sakit Islam Sultan Agung untuk jauh lebih berkembang menuju lebih baik. Rumah Sakit Islam Sultan Agung mendapatkan sertifikat halal pada bagian Instalasi Gizi dari Lembaga Pengkajian Pangan Obat-Obatan dan Kosmetika-Majelis Ulama Indonesia (LPPOM-MUI) Jawa Tengah. Menurut Direktur utama Rumah Sakit Islam Sultan Agung Semarang, Pentingan Sistem Jaminan Halal (SJH) HAS 23000 serta sertifikasi halal untuk Instalasi Gizi bagi Rumah Sakit berkonsep syariah menjadikan pasien aman dan nyaman ketika mengkonsumsi makanan di rumah sakit. Makanan merupakan salah satu terapi nutrisi yang mendukung proses kesembuhan pasien, Bagi rumah sakit yang berkonsep syariah, maka wajib menjamin kehalalan, higienitas dan unsur thayyib (baik)-nya (Masyhudi, 2016). Kota Semarang terdapat 2 Rumah Sakit yang beridentitaskan Islam, yaitu Rumah Sakit Sultan Agung dan Rumah Sakit Roemani yang keduanya memiliki tujuan dakwah dan pengembangan Islam . Namun Rumah Sakit Roemani Muhammadiyah Semarang belum memiliki sertifikat halal terutama untuk bagian instalasi gizi. Dari latar belakang tersebut peneliti ingin meneliti tentang perbedaan tingkat kepuasan makan pasien di Rumah sakit yang bersertifikat halal dengan yang belum bersertifikat halal. .

\section{BAHAN DAN METODE}

Metode penelitian adalah studi komparatif dengan sampel independen menggunakan desain cross -sectional yang dilakukan pada 134 responden (67 responden di Rumah Sakit Islam Sultan Agung dan 67 responden di Rumah Sakit Roemani Muhammadiyah). Penelitian dilakukan pada target sempel yaitu semua pasien yang menjalani perawatan di ruang perawatan Kelas II dan III. Ethical clearance nomor izin etis: 009 / KEPK / EC / 2019 yang dikeluarkan oleh komisi etika penelitian kesehatan Universitas Negeri Semarang. Data kepuasan makan pasien di Rumah Sakit Islam Sultan Agung dan kepuasan makan pasien di $\mathrm{Ru}-$ mah Sakit Roemani Muhammadiyah adalah abnormal dan tidak homogen, analisis menggunakan uji Mann Whitney.

\section{HASIL}

Hasil dari analisis data pada penyelenggaraan makanan di Rumah Sakit Islam Sultan Agung menunjukkan kelompok umur responden terbanyak adalah umur antara 31-49 tahun yakni sebesar 41,8\% dan umur diatas 50 tahun yakni sebesar 40,3\%. Kemudian untuk jenis kelamin responden pada penyelenggaraan makanan di Rumah Sakit Islam Sultan Agung terbanyak adalah kelompok jenis kelamin responden adalah laki-laki yakni sebanyak 38 pasien $(56,7 \%)$ sedangkan pada penyelenggaraan makanan di Rumah Sakit Roemani Muhammadiyah kelompok jenis kelamin responden terbanyak adalah perempuan yakni sebanyak 35 pasien $(52,2 \%)$ (Tabel $1)$.

Berdasarkan hasil penelitian variabel waktu makan terhadap pasien di Rumah Sakit Islam Sultan Agung didapatkan sebanyak $44,8 \%$ responden merasa puas dan $55,2 \%$ sangat puas sedangkan $100 \%$ responden di Rumah Sakit Roemani Muhammadiyah merasa puas dengan ketepatan waktu yang disajikan. Berdasarkan hasil penelitian variabel waktu makan pasien di Rumah Sakit Islam Sultan Agung didapatkan sebanyak 44,8\% responden merasa puas sedangkan $55,2 \%$ sangat puas di Rumah Sakit Roemani Muhammadiyah. Namun pada penyelenggaraan makanan di Rumah Sakit Islam Sultan Agung terdapat $7,5 \%$ responden merasa tidak puas dengan ketepatan waktu makan malam (Tabel 2)

Uji statistik pada indikator ketepatan waktu terdapat perbedaan antara kepuasan makan pasien terhadap variabel waktu makan di Rumah Sakit 
Tabel 1. Karakteristik Responden

\begin{tabular}{|c|c|c|c|c|}
\hline \multirow{2}{*}{ Karakteristik Pasien } & \multicolumn{2}{|c|}{ Rumah Sakit Islam Sultan } & \multicolumn{2}{|c|}{ Rumah Sakit Roemani } \\
\hline & $\mathbf{N}$ & $\%$ & $\mathbf{N}$ & $\%$ \\
\hline \multicolumn{5}{|l|}{ Kelompok Umur (Tahun) } \\
\hline$<20$ & 0 & 0 & 8 & 11,9 \\
\hline $21-30$ & 17 & 25,4 & 17 & 25,4 \\
\hline $31-49$ & 28 & 41,8 & 15 & 22,4 \\
\hline$>50$ & 22 & 32,8 & 27 & 40,3 \\
\hline \multicolumn{5}{|l|}{ Jenis Kelamin } \\
\hline Perempuan & 29 & 43,3 & 35 & 52,2 \\
\hline Laki-laki & 38 & 56,7 & 32 & 47,8 \\
\hline Total & 67 & 100 & 67 & 100 \\
\hline
\end{tabular}

Tabel 2. Perbedaan Hasil Kepuasan Makan Pasien di Rumah Sakit Bersertifikat Halal dengan yang belum Bersertifikat Halal

\begin{tabular}{|c|c|c|c|c|c|c|}
\hline \multirow{2}{*}{ No } & \multirow{2}{*}{ Indikator } & \multicolumn{2}{|c|}{$\begin{array}{c}\text { Rumah Sakit Bersertifikat } \\
\text { Halal }\end{array}$} & \multicolumn{2}{|c|}{$\begin{array}{c}\text { Rumah Sakit Belum Bersertif- } \\
\text { ikat Halal }\end{array}$} & \multirow{2}{*}{$\mathrm{p}$} \\
\hline & & Mean & Std. Deviatoin & Mean & Std. Deviatoin & \\
\hline 1 & $\begin{array}{lll}\text { Kepuasan } & \text { Ketepatan } & \text { Waktu } \\
\text { Makan }\end{array}$ & 10.64 & 1.534 & 9.00 & 0.000 & 0.000 \\
\hline 2 & Kepuasan Penampilan Makanan & 25.13 & 3.219 & 20.73 & 0.539 & 0.000 \\
\hline 3 & Kepuasan Rasa Makanan & 24.39 & 3.330 & 20.81 & 0.987 & 0.000 \\
\hline 4 & $\begin{array}{l}\text { Kepuasan Keramahan Pra- } \\
\text { musaji }\end{array}$ & 34.54 & 4.965 & 30.12 & 0.862 & 0.000 \\
\hline 5 & $\begin{array}{l}\text { Kepuasan Kebersihan Alat Ma- } \\
\text { kanan }\end{array}$ & 31.06 & 3.833 & 27.10 & 0.987 & 0.000 \\
\hline 6 & Kepuasan Variasi Makanan & 14.12 & 1.919 & 12.00 & 0.000 & 0.000 \\
\hline 7 & Kepuasan Makanan & 139.88 & 17.007 & 119.76 & 2.097 & 0.000 \\
\hline
\end{tabular}

bersertifikat halal dengan yang belum bersertifikat halal dengan $\mathrm{p}$ value sebesar 0,000 .

Berdasarkan indicator Kepuasan Pasien terhadap Penampilan Makanan di Rumah Sakit Islam Sultan Agung didapatkan sebanyak 1,5\% responden merasa tidak puas dengan penampilan makanan yang disajikan terutama pada penyajian makanan yang tidak menggugah selera makan dan keseluruhan responden $41,8 \%$ responden merasa puas dan $58,2 \%$ responden merasa sangat puas dengan penampilan makanan yang disajikan di Rumah Sakit Islam Sultan Agung. Sedangkan penyelenggaraan makan di Rumah Sakit Roemani Muhammadiyah didapatkan sebanyak 6,0\% responden merasa tidak puas terhadap warna sayur yang dihidangkan, 4,5\% responden merasa tidak puas dengan bentuk makanan yang disajikan, 3,0\% responden merasa tidak puas dengan porsi lauk dan sebanyak $13,4 \%$ pasien merasa tidak puas dengan penyajian makanan yang tidak menggugah selera (Tabel 2)

Berdasarkan indicator Kepuasan Pasien terhadap Rasa Makanan di Rumah Sakit Islam Sultan Agung terdapat $10,4 \%$ responden merasa tidak puas dengan aroma makanan, sedangkan di Rumah Sakit Roemani Muhammadiyah terdapat 13,4\% merasa tidak puas dengan aroma makanan yang dihidangkan (Tabel
2).

Berdasarkan indicator Kepuasan Pasien terhadap Keramahan Pramusaji di Rumah Sakit Islam Sultan Agung didapatkan hasil 1,5\% responden merasa tidak puas dengan petugas yang kurang bertidak cepat, $1,5 \%$ responden merasa tidak puas dengan petugas yang kurang memiliki pengetahuan luas tentang makanan yang disajikan, $6,0 \%$ responden merasa tidak puas dengan petugas yang kurang dipercaya oleh pasien dalam hal kualitas makanan yang disajikan, 14,9\% responden merasa tidak puas dengan petugas yang kurang meluangkan waktu untuk berkomunikasi dengan pasien, $13,4 \%$ responden merasa tidak puas dengan petugas yang kurang memberikan kepeduliaan terhadap kondisi pasien, $13,4 \%$ responden merasa tidak puas dengan petugas yang kurang berusaha mengetahui kebutuhan pasien, 9,0\% responden merasa tidak puas dengan petugas yang kurang menghibur pasien, 3,0\% responden merasa tidak puas dengan petugas yang kurang berpakaian rapi dan bersih dan 52,2\% responden menyatakan kenyataan keramahaan pramusaji merasa puas dan $46,3 \%$ responden merasa sangat puas. Sedangkan pada penyelenggaraan makanan di Rumah Sakit Roemani Muhammadiyah menyatakan 98,5\% responden merasa puas dengan kenyataan keramahan 
pramusaji (Tabel 2).

Berdasarkan indicator Kepuasan Pasien terhadap Kebersihan Alat Makan di Rumah Sakit Islam Sultan Agung didapatkan hasil sebanyak 4,5\% responden merasa tidak puas dengan penyajian makanan yang tidak disediakan gelas, 4,5\% responden merasa tidak puas dengan penyajian makanan yang tidak disediakan tisu, $9,0 \%$ responden merasa tidak puas dengan makanan yang dihidangkan kurang lengkap dan $52,2 \%$ responden merasa puas dan $47,8 \%$ merasa sangat puas dengan kenyataan kebersihan alat makan di Rumah Sakit Islam Sultan Agung. Sedangkan pada penyelenggaraan makanan di Rumah Sakit Roemani Muhammadiyah menyatakan 98,5\% responden merasa puas dengan kenyataan kebersihaan alat makan (Tabel 2).

Berdasarkan indicator Kepuasan Pasien terhadap Variasi Makanan di Rumah Sakit Islam Sultan Agung didapatkan sebanyak 50,7\% merasa sangat puas dengan kenyataan variasi makanan di Rumah Sakit Islam Sultan Agung dan pada penyelenggaraan makanan di Rumah Sakit Roemani Muhammadiyah didapatkan $100 \%$ responden merasa puas dengan kenyataan variasi makanan di Rumah Sakit Roemani Muhammadiyah.

Berdasarkan hasil penelitian diketahui rata-rata tiap indikator penilaian kepuasan makan pada penyelenggaraan makan di Rumah Sakit Islam Sulan Agung lebih tinggi dari pada penyelenggaraan makan di Rumah Sakit Roemani Muhammadiyah. Selanjutnya pada uji statistik didapatkan hasil pada kepuasan makan total bahwa ada perbedaan antara kepuasan makan pasien di Rumah Sakit bersertifikat halal dengan yang belum bersertifikat halal dengan $\mathrm{p}$ value 0,000 (Tabel 2).

\section{PEMBAHASAN}

Hasil penelitian menunjukkan bahwa terdapat perbedaan kepuasan pasien terhadap waktu makan. Menurut penelitian tingkat kepuasan di Rumah Sakit Umum Daerah Kota Makassar ketapatan waktu merupakan cara untuk menghindari pasien mengkonsumsi makanan dari luar Rumah Sakit dan berharap pasien menghabiskan makanan yang disajikan dan bila makanan yang disajikan terlambat pasien yang sudah lapar akan memakan makanan yang dibawakankan oleh pembesuk atau keluarganya (Rochimiwati et al, 2016). Menurut penelitian yang dilakukan di Rumah Sakit dr Soeradji Titonegoro didapatkan bawah terdapat hubungan bermakna antara ketepatan jam pemberian makanan dengan tingkat kepuasan pasien terhadap pelayanan makanan dengan $(p=0,017)$ (Widosari, 2017). Islam memandang waktu sebagai kehidupan terus menerus berlalu tanpa seorang pun yang bisa memajukan atau mengundurnya sebab penetapan waktu itu merupakan hak preogratif Allah SWT, oleh karena itu islam memandang penting pengelolaan dan pengaturan waktu dengan sebaikbaiknya sehingga tidak ada yang terbuang sebaliknya pengelolaan waktu itu dapat memberikan kemanfaatan dan kebahagian, baik bagi diri sendiri maupun masyarakat, di dunia maupun di akhirat kelak (Sabri, 2012).

Kemudian, terdapat perbedaan antara kepuasan makan pasien terhadap variabel penampilan makanan di Rumah Sakit bersertifikat halal dengan yang belum bersertifikkat halal dengan $p$ value yaitu 0,000 . Menurut penelitian Lumbantoruan (2012) Pasien yang berpendapat penampilan makanan tidak menarik akan lebih banyak menyisakan makanan sedangkan pasien yang berpendapat penampilan makanan sudah menarik akan menyisakan makanan lebih sedikit. Menurut $\mathrm{Pu}-$ tri (2017) ada hubungan antara penampilan lauk nabati, sayur dan buah terhadap sisa makanan pasien kanker di RSUD Tugurejo Semarang. Warna menjadi salah satu hal utama dalam merangsang indera penglihatan dan menjadi salah satu bagian dari penampilan yang menjadi bentuk pertama interaksi sensorik dengan makanan (Habibah et al, 2017)

Hasil penelitian menunjukkan bahwa terdapat perbedaan antara kepuasan makan pasien terhadap variabel rasa makanan di Rumah Sakit bersertifikat halal dengan yang belum bersertifikat halal dengan $p$ value 0,000 . Menurut penelitian sebelumnya terdapat hubungan antara rasa makanan dengan sisa makanan (Ariyanti, 2017). Cita rasa dapat meningkatkan selara makan pasien yang berdampak pada peningkatan konsumsi makanan pada pasien dan akan mempengaruhi terjadinya sisa makanan (Liber, 2014). Rasa makanan ditimbulkan oleh terjadinya berbagai indera penglihatan, indera penciuman, indera pengecap dan makanan yang memiliki rasa yang tinggi adalah makanan yang menarik, menyebarkan bau yang sedap dan memberikan rasa yang lezat (Kumboyono et al, 21013). Menurut Kustiyoasih et al (2016) Indikator cita rasa memiliki keakuratan dalam menilai kualitas produk makanan karena rasa dipengaruhi oleh beberapa faktor seperti temperatur dan tingkat sensitivitas rasa peroranagan sehingga sangat berpengaruh bagi konsumen. Hidangan makanan dalam keadaan panas dapat menimbulkan aroma yang mampu menjadi daya tarik makanan untuk dikonsumsi (Widyastuti et al, 2014).

Hasil penelitian pada penyelenggaraan makanan di Rumah Sakit Islam Sultan Agung terdapat beberapa responden merasa tidak puas dengan petugas yang kurang bertindak cepat dalam memenuhi permintaan pasien, petugas kurang yang mempunyai pengetahuan yang luas tentang makanan yang disajikan, petugas yang kurang dapat dipercaya oleh pasien dalam hal kualitas makanan yang disajikan, petugas yang kurang meluangkan waktu khusus untuk berkomunikasi dengan pasien, petugas yang kurang memberikan kepedulian terhadap kondisi pasien, petugas yang kurang berusaha mengetahui kebutuhan pasien, petugas yang kurang menghibur pasien, dan petugas berpakaian kurang rapi dan bersih. Namun pada umumnya banyak responden yang merasa sangat puas dengan keramahan pramusaji di Rumah Sakit Islam Sultan Agung. Konsep Islam mengajarkan bahwa dalam memberikan layanan dari usaha yang dijalankan baik itu berupa barang atau jasa jangan memberikan pelayanan yang buruk, melainkan memberikan pelayanan yang baik kepada orang. Hal ini sesuai dengan firman Allah dalam Al-Qur'an surah Ali Imran:

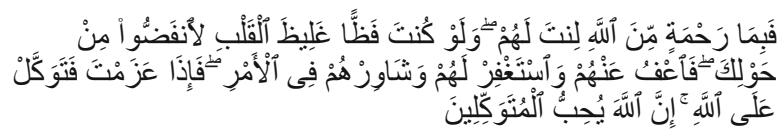


Artinya : "Maka disebabkan rahmat dari Allah lah kamu berlaku lemah lembut terhadap mereka, sekiranya kamu bersikap keras lagi berhati kasar, tentulah mereka menjauhkan diri dari sekelilingmu." (Qs. Ali Imran: 159)

Menurut penelitian Ramadhan (2013) pelanggan akan merasa puas bila mendapatkan pelayanan yang baik atau sesui dengan harapan, pasien adalah seorang pelanggan dan kepuasan pelanggan sangat ditekankan dalam ajaran Islam yaitu dengan memposisikan pelanggan sebagai raja yang harus dilayani dengan sebaik-baiknya.

$$
\text { سيدالقوم خادمهم }
$$

"Pemimpin sebuah kaum pada hakekatnya adalah pelayanan bagi mereka"

Artinya, Kalau kita mau sukses dan berhasil dalam memimpin atau mengelola perusahaan maka kita harus mampu menjadi pelayan yang baik bagi stakeholder, demikian jika kalau rumah sakit mau berhasil sebagai rumah sakit yang dapat dipercaya masyarakat harus bisa memberikan pelayanan yang baik dam layanan yang prima (Ramadhan, 2013).

Kebersihan peralatan makanan berpengaruh terhadap kesehatan pasien penyebab kontaminasi bakteri pada makanan antara lain kontak makanan dengan peralatan yang tidak bersih atau mengandung bakteri, penjamah makanan yang tidak menerapkan perilaku hygiene, penggunaan air kotor (Akanele, 2016). Kementerian Kesehatan (2013) tentang higiene sanitasi menyatakan bahwa, wadah makanan yang digunakan terbuat dari bahan yang aman dari zat yang beracun yang dapat membahayakan tubuh. Peralatan yang akan digunakan sebaiknya dicuci bersih untuk mengurangi jumlah bakteri pada alat yang akan digunakan. Kebersihan dalam Islam merupak aspek yang sangat penting seperti sabda Rasulullah :

$$
\begin{aligned}
& \text { النَّظَافَةُ مِنَ الْإِيْمَانِ } \\
& \text { "Kebersihan merupakan sebagian dari } \\
& \text { iman” (H.R. Ahmad) }
\end{aligned}
$$

Adapun kepuasan pasien terhadap variasi makanan menunjukkan adanya perbedaan yang signifikan. Menurut penelitian Handayani (2016) Variasi makanan sangat berpengaruh nyata terhadap status gizi. Hal ini dikarenakan setiap makanan yang dikonsumsi mengandung berbagai jenis zat yang dibutuhkan oleh tubuh. Menurut Depkes RI (2007) Menu yang bervariasi adalah tidak boleh terjadi penggunaan hidangan yang sama dalam satu siklus menu atau tidak boleh terjadi metode pemasakan yang sama dalam siklus makanan. Variasi menu makananan akan merangsang pasien dalam meningkatkan selera makan, Menu yang bervariasi akan menambah gairah untuk makan sehingga makanan yang disajikan akan habis dimakan oleh pasien (Septiana, 2010). Variasi menu yang tersusun oleh kombinasi bahan makanan yang diperhitungkan dengan tepat akan memberikan hidangan sehat baik secara kualitas dan kuantitas (Sediaoetama, 2006). Uji statistik pada penelitian didapatkan hasil ada perbedaan antara kepuasan makan pasien terhadap variabel variasi makanan di Rumah Sakit bersertifikat halal dengan yang belum bersertifikat halal dengan $p$ value yaitu 0,000. Menyediakan variasi makanan merupakan salah satu cara untuk mengatasi rasa bosan yang mengurangi selera makan.

Pemilihan sistem pada penyelenggaraan makanan khususnya pasien akan berpengaruh terhadap input, process, dan output dimana apabila input dan process kurang baik maka akan menghasilkan output (mutu makanan) yang kurang baik pula sehingga berpengaruh pada kepuasan pasien (Pramono, 2014). Dalam penyelenggaraan makanan, harus merupakan makanan yang halal dan thayyib dan ada baiknya jika penyelenggaraan makanan tersebut memiliki sertifikat halal. Sertifikat halal tidak hanya memberi manfaat perlindungan hukum hak-hak konsumen muslim terhadap produk yang tidak halal, tapi juga meningkatkan nilai jual produk pelaku usaha, karena konsumen tidak akan ragu lagi untuk membeli produk yang diperdagangkan pelaku usaha dan logo sertifikat halal memberikan kepastian hukum kepada konsumen muslim bahwa produk tersebut halal sesuai syariat Islam (Syafrida, 2016). Sertifikasi halal sebagai bentuk pengujian terhadap makanan mulai dari persiapan, penyembelihan, pembersihan, proses, perwatan, pembasmian kuman, penyimpanan, pengangkutan, sebaik mungkin sebaik praktik manajemennya (Wasikito, 2015).

Makanan yang halal dapat menjadi makanan haram apabila dalam tahan produksinya bercampur atau terkontaminasi produk haram, sehingga perlu adanya pengendalian titik kritis kehalalan pangan setiap tahap produksinya (Hasan, 2013: Demirci, Soon dan Wallace, 2016). Sebagaimana dalam Al-Qur'an tertera dalam surah Al- Baqarah ayat 168 dan AlMa'idah ayat 3.

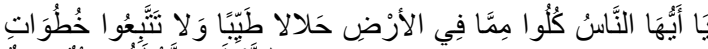

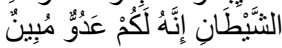

" Hai sekalian manusia, makanlah yang halal lagi baik dan apa yang terdapat dibumi, dan janganlah kamu mengikuti langkah-langkah syetan, karena sesungguhnya syetan itu musuh yang nyata bagimu." (QS. Al-Baqarah (2): 168).

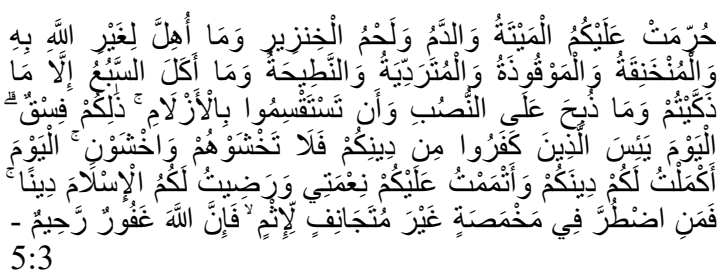

“ Diharamkan bagimu (memakan) bangkai, darah, daging babi, (daging hewan) yang disembelih atas nama selain Allah, yang tercekik yang dipukul, yang jatuh, yang ditanduk, dan yang diterkam bintang buas, kecuali yang sempat kamu menyembalihnya, dan (diharamkan bagimu) yang disembelih untuk berhala. Dan (diharamkan juga) mengundi nasib dengan anak panah, (mengundi nasib dengan anak panah itu) adalah kefaksikan. Pada hari ini orang-orang kafir telah putus asa untuk (mengalahkan) agamamu, sebab itu janganlah kamu takut kepada mereka dan takutlah kepada-Ku. Pada hari ini telah Kusempurnakan untuk kamu agamamu, dan telah Ku cukupkan kepadamu nikmat-Ku, dan telah Ku-ridai Islam itu jadi agama bagimu. Maka barang siapa terpaksa karena kelapa- 
ran tanpa sengaja berbuat dosa, sesungguhnya Allah Maha Pengampun lagi Maha Penyayang”. (AlMa'idah :3).

Konsep Islam mengajarkan bahwa dalam memberikan layanan dari usaha yang dijalankan baik itu berupa makanan atau jasa jangan memberikan yang buruk atau tidak berkualitas, melainkan yang berkualitas kepada orang lain (Aldursanie, 2013).

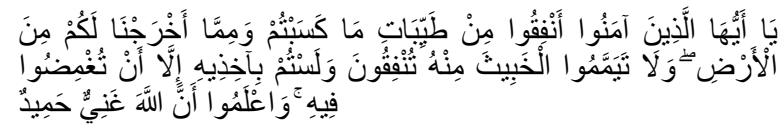

Artinya : "Hai orang-orang yang beriman, nafkahlah (dijalan Allah) sebagaimana dari hasil usahamu yang baik-baik dan sebagai dari apa yang kami keluarkan dari bumi untuk kamu. Dan janganlah kamu memilih yang buruk-buruk lalu kamu menafkahkan daripadanya, padahal kamu sendiri tidak mau mengambilnya melainkan dengan memincangkan mata terhadapnya. Dan ketahuilah, bahwa Allah Maha Lagi Maha Terpuji” (Q.S Al Baqarah : 267).

Dari hasil penelitian ini memiliki kontribusi besar dalam islamisasi dari segi penyelenggaraan makanan yang bersertifikat halal dengan adanya sertifikat halal memberikan pengaruh positif dari pasien dan masyarakat tentang penyelenggaraan makanan yang ada di Rumah Sakit dan memberikan evaluasi pada Rumah Sakit untuk meningkatkan perhatian terhadap pelayanan terutama pada penyelenggaraan makanan

\section{KESIMPULAN}

Ada perbedaan tingkat kepuasan makan pasien pada beberapa aspek (waktu makan, penampilan makanan, rasa makanan, keramahan pramusaji, kebersihan alat makan, variasi makan) di Rumah Sakit bersertifikat halal dengan yang belum bersertifikat halal .

\section{DAFTAR PUSTAKA}

Aldursanie, R. (2013). Kualitas Pelayanan dalam Islam. Retrieved Desember 12, 2018.

Al-Fauzan. (2009). Muqaddimah al-Luqatat fi ma Yubah wa Yuhram min al-At'imah wa alMashrubat. Retrieved Desember 23, 2018, from http://al-atsariyyah.com.

Akanele, E. (2016). Microbiological Contamination of Food: The Mechanisms, Impacts And Prevention, International Journal of Scientific \& Technology Research Vol 5(3). Available at:www.ijstr.org.

Ariyanti, V. Widyaningsih, E. N. and Rauf, R. (2017). Hubungan antara Karakteristik Sensorik Makanan dengan Sisa Makanan Biasa pada Pasien Rawat Inap RSUD DR. Soeratno, Gemolong, Kabupaten Sragen. Jurnal Kesehatan Vol. 10. hal. 23

Asmuji. (2012). Manajemenatan: Konsep dan Aplikas Keperawi. Jogjakarta: Ar-Ruzz Media.

Atma, Y. Taufik, M. and Septiono, H . (2018). Identifikasi Resiko Titik Kritis Kehalalan Produk Pangan : Studi Produk Bioteknologi. Jurnal Teknologi, Vol.10.hal.64.
Azizah, M. (2017). Instrumen Labelisasi dan Sertifikasi halal sebagai perlindungan hukum terhadap konsumen muslim dalam wacana hukukm ekonomi islam di Indonesia. Jurnal Al-'Adl, Vol.10.hal.143.

Badri, M. A. (2008). Sifat peniagaan Nabi. Bogor: Pustaka Darul Ilmi.

Demirci M. N. Soon, J. M and Wallace, C. A. (2016). Positioning Food Safety in Halal Assurance, Food Contol, Elsevier Ltd. doi: 10.1016/ j.foodcont.2016.05.059

Fadhila, M.F. Wahyuningsih, N. E.and Hanani, Y. D. (2015). Hubungan Higiene Sanitasi dengan Kualitas Bakteriologis pada Alat Makan Pedagang di Wilayah Sekitar Kampus UNDIP Tembalang. Semarang : Universitas Diponegoro. Jurnal Kesehatan Masyarakat Vol. 3 No. 3. hal. 771.

Faidah, M. (2017). Sertifikasi Halal di Indonesia dari Civil Society Menuju Relasi Kuasa Antara Negara dan Agama. ISLAMICA, Vol.11.hal.453.

Fajriati, I. (2010). Teknologi Pangan dalam wacana Halal dan Haram. Jurnal Al-Qanun, Vol. 13.hal.398.

Giese and Cote. (2002). Defining Consumer Satisfaction. Academy of Marketing Science Review.

Habiba, R. A. and Adriani, M. (2017). Hubungan Depresi, Asupan, dan Penampilan Makanan dengan Sisa Makan Pagi Pasien Rawat Inap (Studi di Rumah Sakit Islam Jemursari Surabaya). doi: 10.2473/amt.v1i3.2017.198208.

Hafid, H. P. (2016). Pengaruh Pelayanan dengan Prinsip-Prinsip Syariah Terhadap Kepuasan pasien pada RS Ibnu Sina Makssar [Undergraduate Thesis]. Makassar : Universitas Islam Negeri Alauddin.

Hamidah, S. (2015). Menu Yang Halal dan Thoyib. [Undergraduate Thesis]. Yogyakarta: Universitas Negeri Yogyakarta.

Handayani, S. M. (2016). Pengaruh Variasi Konsumsi Pangan TerhadapStatus Gizi Pelajar Kelas XI SMA Panudi Luhur dan SMAN 8 Yogyakarta. [Undergraduate Thesis]. Yogyakarta : Fakultas Keguruan dan Ilmu Pendidikan Universitas Sanata Dharma .

Hasan, K. (2014). Kepastian hukum sertifikasi dan labelisasi produk pangan. Jurnal Dinamika Hukum, Vol.14, hal. 227-238.

Hasanah, U. (2016). Peningkatan Kestabilan Enzim Protease dari Bacillus Subtilis ITBCCB148 dengan Amobilisasi Menggunakan Zeolit [Undergraduate Thesis]. Bandar Lampung: Fakultas Matematika dan Ilmu Pengetahuan Alam Universitas Lampung.

Hidayat, A. S. (2015). Sertifikat Halal dan Sertifikasi Non Halal Pada Produk Pangan Industri. Jurnal Ahkam, Vol. XV.hal. 200

Ilham. (2017). Analisis Perbandingan terhadap Sistem Penyembelihan Hewan secara Stunning dengan manual [Undergraduate Thesis]. Makassar : Fakultas Syari'ah dan Hukum 
UIN Alauddin Makassar.

Indonesian Ulema Council. (2008). Panduan Umum Sistem Jaminan Halal. Jakarta: Majelis Ulama Indonesia.

indonesian Ulema Council.(2016). Retrieved Desember 9, 2018, from Lembaga Pengkajian Pangan Obat obatan dan Kosmetika Majelis Ulama Indonesia: www.halalmui.org

Irawan, B. (2016). Analisis Hukum Islam Terhadap Pelaksanaan Penyembelihan Ayam di Pasar PON Kabupaten Jombang. Jurnal Penelitian Hukum Islam, Vol. 01.hal.89.

Khomariyah, N. (2017). Pengaruh Kesadaran Halal, Islamic Branding dan Product Ingredients Terhadap minat beliproduk luwak white koffie (studi pada masyarakat Desa Putatsewu, Jawa tengah, Sukodono, Sragen [Undergraduate Thesis]. Surakarta : IAN Surakarta.

Kotler, P. (2009). Manajemen Pemasaran. Jakarta : Erlangga.

Kumboyono and Vina. (2013). Indikator Kebutuhan Nutrisi oleh Pasien Rawat Inap Rumah Sakit Tentara dr. Soepraoen Malang. Jurnal Ners Vol. 8 No. 2. hal. 187

Kuntoro, W. (2017). Kepuasan Pasien Terhadap Kualitas Pelayanan di Tempat Pendaftaran Pasien Rawat Jalan Puskesmas Kretek Bantul Yogyakarta. Jurnal Kesehatan Vokasional, Vol. 2.hal.141.

Kurniawati, L. (2018). Pengaruh Label Halal dan Harga Terhadap Kepuasan Konsumen Kosmetik Wardah pada Mahasiswi Fakultas Syariah Jurusan Muamalah IAIN Ponorogo [Undergraduate Thesis]. Ponorogo: Insitut Agama Islam Negeri Ponorogo.

Kustiyoasih, M.P., Andriani, M. and Nindya, T.S. (2016). Penyelenggaraan Makanan dan Kepuasan Konsumen di Kantin Lantai 2 Rumah Sakit Universitas Airlangga Surabaya. Media Gizi Indonesia Vol. 11. No. 1 . hal 1116

Liber, D. R. (2014). Peningkatan Kualitas Cita Rasa Makanan Rumah Sakit untuk Mempercepat Penyembuhan Pasien. Jurnal Mutu Pangan, Vol 1, hal. 83-90.

Lukmanudin, M. I. (2015). Legistimasi Hadis Pelarangan Penggunaan Alkohol Dalam Pengobatan. Journal of Qur'an and Hadist Studies, Vol. 4, hlm. 88.

Lumbantoruan, D. B. S. (2012). Hubungan Penampilan Makanan dan Faktor Lainnya dengan Sisa Makan Biasa Pasien Kelas 3 Seruni RS Puri Cinera Depok Bulan Pasien April-Mei 2012 [Undergraduate Thesis]. Depok: Fakultas Kesehatan Masyarakat Universitas Indonesia.

Marisdayana, R. Sahara, P. H and Yosefin, H. (2017). Teknik Pencucian Alat Makan, Personal Hygiene terhadap Kontaminasi Bakteri pada Alat Makan. Jambi : STIKES Harapan Ibu Jambi. Jurnal Endurance Vol. 2 No.3.Hal. 377.

Masyhudi, H. (2016). RSI Sultan Agung Semarang
Peroleh Sertifikat Halal. (L. MUI, Interviewer)

Maulidia, R. (2013). Urgensi Regulasi dan Edukasi Produk Halal bagi Konsumen. Jurnal Justitia Islamica, Vol.10.hal.361.

Ministry of Health RI. (2007). Pedoman Penyelenggaraan Makanan Rumah Sakit. Jakarta : Direktorat Bina Pelayanan Medik Dasar, Direktorat Jenderal Bina Pelyanan Medik.

Ministry of Health. (2013). Pedoman Pelayanan Gizi Rumah Sakit. Jakarta: Menteri Kesehatan Republik Indonesia.

Muchtar, M. A. (2013). Pentingnya Sertifikasi Halal Melalui LPPOM dan MUI. Available at: http://www.madlinatualim.com

Muljono, D. \&. (2008). Pengukuran Dalam Bidang Pendidikan. Jakarta: PT. Grasindo.

Notoatmodjo, S. (2010). Metodologi Penelitian Kesehatan. hal 115-130 Jakarta: Rineka Chipta.

Pramono, A.,and Widyastuti, N. (2014). Manajemen Jasa Boga. Yogyakarta: Graha Ilmu.

Prasetyani, L.N. (2016). Hubungan Sikap Ahli Gizi dan Pramusaji terhadap Tingkat Kepuasan Pasein Rawat Inap Kelas III Rumah Sakit Umum Daerah (RSUD) Kota Salatiga [Undergraduate Thesis]. Surakarta : Universitas Muhammadiyah Surakarta.

Presiden Republik Indonesia. (2014). Jaminan Produk Halal. Undang-undang nomor 33 tahun 2014.

Pohan. (2006). Jaminan Mutu Layanan kesehatan : dasar-dasar pengertian dan penerapan. 2006: Buku Kedokteran EGC.

Nasution, P. H. (2017). Analisis Tingkat Kepuasan Pasien Rawat Inap Terhadap Pelayanan Makanan di Rumah Sakit Umum Haji Medan [Undergraduate Thesis]. Medan: Fakultas Kesehatan Masyarakat Universitas Sumatera Utara.

Putri, A. R. (2017). Hubungan antara Besar Porsi, Aroma dan Penampilan Makanan Terhadap Sisa Makanan pada Pasien Kanker di RSUD Tugurejo Semarang [Tesis]. Semarang: Universitas Muhammadiyah Semarang.

Rachmawati, I and Afridah, W. (2014). Mutu Pelayanan Gizi dengan Tingkat Kepuasan Pasien. Jurnal Vol 7 No 2. hal 197

Rochimiwati, S. N. , Mas'ud, H.\&Asriani, R. (2016). Tingkat Kepuasan Pasien Terhadap Penyajian Makanan di RSUD Kota Makassar. Jurnal Media Gizi Pangan, Vol.XXI. hal 23

Ramadhan, M. N. A. (2013). Analisis Faktor-Faktor yang Mempengaruhi Kepuasan Pelanggan Servis Berkala pada Dealer Nissan Basuki Rahamat di Kota Surabaya [Skripsi]. Malang: Fakultas Ekonomi Universitas Islam Negeri Maulana Malik Ibrahim.

Rusman, S. (2016). Analisis Maqashid Syariah terhadap fatwa MUI mengenai halal haramnya bisnis MLM (Multi-Level Marketing) [Undergraduate Thesis]. Makassar: Fakultas Syari'ah dan Hukum UIN Alauddin Makassar. 
Sabri, A. (2012). Pengelolaan Waktu dalam Pelaksanaan Pendidikan Islam. Jurnal AlTa'lim Jilid 1 Nomor 3. hal 186.

Salehudin, I. (2010). Halal Literacy: A Concept Exploration and Measurement Validation. ASEAN Marketing Journal, II, Hal. 1-12.

Sediaoetama. (2006). Ilmu gizi mahasiswa dan profesi jilid II. Jakarta: Dian Rakyat.

Segati, A. (2018). Pengaruh Persepsi Sertifikasi Halal, Kualitas Produk, dan Harga Terhadap Persepsi Peningkatan Penjualan. Yogyakarta : Universitas Islam Indonesia. Jurnal Ekonomi dan Bisnis Islam Vol. 3 No. 2. hal. 165.

Setiawati, L. J. (2017). Pengaruh Komitmen Manajemen Terhadap Kualitas Layanan dan Kepuasan Pelanggan di Rumah Sakit Umum Daerah. Surabaya : Universitas Pelita Harapan. Available at: http://researchreport.umm.ac.id/index.php/research-report/ article/viewFile/1319/1537.

Septiana, S.L. (2010). Faktor-faktor yang Berhubungan dengan Konsumsi Energi dan Protein pada Peserta Didik di Man Insan Cendika Serpong Tahun 2010 [Undergraduate Thesis]. Jakarta : Universitas Islam Negeri Syarif Hidayatullah.

Sholeh, A. N. (2015). Halal Jadi Tren Global. GATRA. Available at : http: majalah.gatra.com/2015.07-13/majalah/ artikel.php?pil=23\&id: 159808 .

Sulistiadi, W. (2016). Potensi Penerapan Maqashid Syariah Dalam Rumah Sakit Syariah Di Indonesia. Batusangkar International Conference, hal.15-16.

Suyadi. (2014). Pengaruh kepercayaan dan kenyamanan terhadap keputusan pembelian online (studi pada pelanggan website ride inc). Jurnal Admintrasi Bisnis, Vol.8.hal.4.

Syafrida. (2016). Setifikat Halal pada Produk Makanan dan Minuman memberi perlindungan dan kepastian hukukm hak-hak konsumen muslim. Jurnal Hukum ADIL, Vol.7.hal.171.

Syifa, H. A. (2013). Retrieved Maret 17, 2013, from Urgensi Sertifikasi Halal: www.coretahanifah.wordpress.com.

The Pew Forum on Religion and Public Life. (2010). Pew-Templeton Global Religious Future. Retrieved December 12, 2018, from Pewforum.org: www.globalreligiousfutures.org

Wafa'. (2011). Hubungan Antara Higiene Sanitasi Makanan dengan Keberadaan Bakteri Escherichia coli Pada Peralatan Makan [Undergraduate Thesis]. Jember: Universitas Jember.

Wauneta, N. (2016). Pengaruh lokasi, Keragaman Produk, dan Harga Terhadap Minat Beli Konsumen pada Giant Ekspres Cabang Alauddin Makassar [Tesis]. Makassar: UIN Alauddin Makassar.

Wasikito, D. (2015). Pengaruh sertifikasi halal, kesadaran halal, dan bahan makanan terhadap minat beli produk makanan halal
[Undergraduate Thesis]. Yogyakarta: Fakultas Ekonomi Universitas Negeri Yogyakarta.

Windisukma, D. K. (2015). Pengaruh Kesadaran Halal terhadap sikap dan Implikasinya terhadap minat beli ulang [Undergraduate Thesis] Semarang: Fakultas Ekonomika dan Bisnis Universitas Diponegoro.

Al-Qur'an Al-Baqarah : 168

Al-Qur'an Al-Baqarah : 172

Al-Qur'an Al-Baqarah : 267

Al-Qur'an Al-Jatsiyah : 18

Al-Qur'an Almaidah : 3

Al-Qur'an Almaidah : 5

Al-Qur'an Almaidah :88

Al-Qur'an An Nahl : 114 